DOI https://doi.org/10.30525/978-9934-26-111-4-49

\title{
ДОПОСІВНА ОБРОБКА НАСІННЯ ТА ПОЗАКОРЕНЕВЕ ПІДЖИВЛЕННЯ - ЯК СПОСІБ ВПЛИВУ НА РІСТ \\ І РОЗВИТОК РОСЛИН ТА ФОРМУВАННЯ ПОКАЗНИКІВ ІНДИВІДУАЛЬНОЇ ПРОДУКТИВНОСТІ СӦ̈
}

\author{
Молдован В. Г. \\ кандидат сільськогосподарських наук, стариий науковий співробітник, \\ директор \\ Хмельницька державна сільськогосподарська дослідна станція \\ Інституту кормів та сільського господарства Поділля \\ Національної академї аграрних наук Украӥни
}

\section{Молдован Ж. А.}

кандидат сільськогосподарських наук, старший науковий співробітник, завідувач сектору сучасних технологій у рослинництві

Хмельницька державна сільськогосподарська дослідна станція

Інституту кормів та сільського господарства Поділля

Національної академї аграрних наук України

с. Самчики, Старокостянтинівський район,

Хмельницька область, Украӥна

В умовах сьогодення при вирощуванні сої важливого значення набувають питання розробки та впровадження сучасних технологій, які б базувалися на раціональному використанні генетичного потенціалу продуктивності сорту, оптимізації умов мінерального живлення із врахуванням потреби рослин в елементах живлення за етапами органогенезу. Результати наукових досліджень у різних грунтовокліматичних зонах України показали, що використання сучасних регуляторів росту та мікродобрив при вирощуванні сої активізує формування листкової поверхні та діяльність симбіотичного апарату [1, с. 5; 2, с. 7 ], накопичення сухої речовини [3, с. 88], зумовлює збільшення кількості бобів та маси насінин на одній рослині [4, с. 6; 5 , с. 80], підвищення продуктивності фітоценозів сої та покращення якісних показників насіння [6, С. 98].

Дослідження проводилися Хмельницькою ДСГДС ІКСГП НААН впродовж 2016-2018 pp. на чорноземах опідзолених, середньосуглинкових. Грунт достатньо насичений основами - 39,8-42,0 мг екв. 
на 100 г, має гідролітичну кислотність 1,8-2,7 мг екв. на 100 г грунту. Вміст гумусу (за Тюріним) - 3,2 \%. Формами поживних речовин середньо забезпечений: вміст азоту, що легко гідролізується, 14,4-16,6, фосфору рухомого - 11,0-12,0, калію обмінного - 7,8-8,0 мг на 100 г грунту.

Гідротермічні умови в різні періоди розвитку рослин сої мали істотні відхилення від середньобагаторічних показників, що, як наслідок, певним чином впливало на їх ріст, розвиток, утворення бобів, формування та налив насіння.

За результатами проведених досліджень та отриманих даних нами встановлено, що допосівна обробка насіння та позакореневе підживлення посівів сої стимулятором росту ВИМПЕЛ та комплексними мікродобривами Оракул позитивно впливають на ріст і розвиток рослин сої, формування показників індивідуальної продуктивності та урожайності насіння.

Зокрема, допосівна обробка насіння препаратом для обробки насіння ВИМПЕЛ-К та комплексними мікродобривами Оракул-насіння та Оракул-молібден, навіть в умовах дефіциту вологи в посівному шарі грунту, скорочують період «сівба-сходи» на 1-2 дні порівняно 3 необробленими ділянками, тоді як досліджувані способи позакореневого підживлення зумовили подовження вегетаційного періоду сої, у середньому, на 2-5 днів.

Висота рослин сої та висота прикріплення нижнього бобу також, певним чином, залежали від способів позакореневого підживлення. У середньому за три роки досліджень висота прикріплення нижнього бобу коливалася від 9,1 см до 14,0 см. Встановлено, що покращення мінерального живлення зменшувало, у середньому, висоту прикріплення нижнього бобу на $0,8-1,8$ см за внесення $\mathrm{N}_{32} \mathrm{P}_{32} \mathrm{~K}_{32}$ та на 0,9-1,8 см - за внесення $\mathrm{N}_{48} \mathrm{P}_{48} \mathrm{~K}_{48}$ порівняно 3 варіантами, де не вносились мінеральні добрива. Способи допосівної обробки насіння та позакореневого підживлення зменшували висоту прикріплення нижнього бобу на 0,2-4,1 см залежно від рівня мінерального живлення. Найнижчі показники прикріплення нижнього бобу $(9,1-12,1$ см) відмічено за внесення $\mathrm{N}_{48} \mathrm{P}_{48} \mathrm{~K}_{48}$, тоді як на фоні природної родючості вони зростали до 10,9-14,0 см.

У більшості випадків зміна урожайності під впливом зовнішніх умов пов'язана із зміною кількості насінин, оскільки саме вона, насамперед, визначається процесом формування урожаю i, як наслідок, являє собою першу можливість для рослини регулювати елементи продуктивності 3 урахуванням навколишнього середовища. Нами 
встановлено, що мінеральне живлення, способи обробки насіння та позакореневого підживлення мали значний вплив на формування показників індивідуальної продуктивності: кількість бобів на рослині, кількість насінин у бобі, масу 1000 насінин, індекс урожаю.

Проведення допосівної обробки насіння та позакореневого підживлення стимуляторами для обробки насіння та посівів, комплексними мікродобривами та добривами-компенсаторами, за різних рівнів мінерального живлення, зумовлювало зростання кількості бобів на рослині, у середньому, на 2-18 шт. порівняно 3 контролем. Однак, вони не мали істотного впливу на формування кількості насінин у бобі, яка становила 2,2-2,4 шт.

Маса 1000 насінин - другий показник, що має вплив на формування індивідуальної продуктивності та урожайності насіння сої. У наших дослідженнях маса 1000 насінин змінювалася, як за способами обробки насіння та позакореневого підживлення, так і за рівнями мінерального живлення (рис. 1).

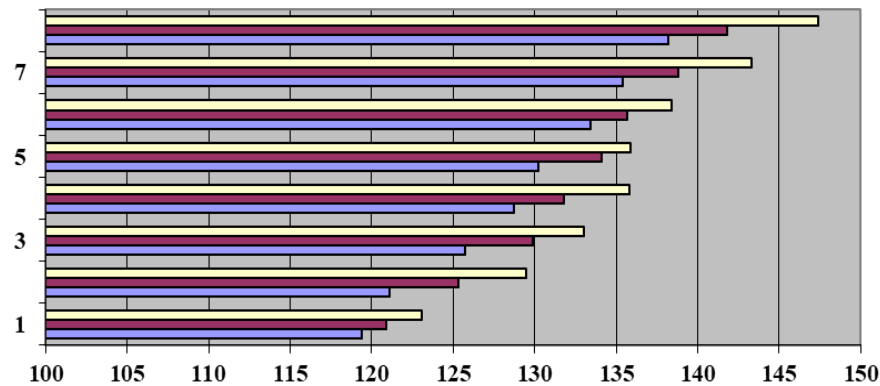

\section{Рисунок 1 - Маса 1000 насінин сої залежно від рівня} мінерального живлення, способів обробки насіння та позакореневого підживлення, г (у середньому за 2016-2018 р.)

Примітка: 1 - Без обробки насіння та посівів (контроль); 2 Обробка насіння: Вимпел $K-0,5$ л/т + Оракул насіння, 1,0 л/т + Оракул молібден, 0,5 л/т; 3 - Обробка посівів у фазу 2 - 3 справжніх листки: Вимпел, 0,5 л/га; 4 - Обробка посівів у фазу початку бутонізації: Вимпел, 0,5 л/га + Оракул бор, 1,0 л/га + Оракул сірка, 2,0 л/га + Оракул цинк, 1,0 л/га; 5 - Обробка насіння Вимпел К - 0,5 л/т + обробка посівів у фазу 2-3 справжніх листки: Вимпел, 0,5 л/га; 6 -Обробка насіння: Вимпел К $-0,5$ л/т + 
Оракул насіння, 1,0 л/т + Оракул молібден, 0,5 л/т + обробка посівів у фазу 2-3 справжніх листки: Вимпел, 0,5 л/га; 7 - Обробка посівів у фазу 2-3 справжніх листки: Вимпел, 0,5 л/га + обробка посівів у фазу початку бутонізації: Вимпел, 0,5 л/га + Оракул бор, 1,0 л/га + Оракул сірка, 2,0 л/га + Оракул цинк, 1,0 л/га; 8 - Обробка насіння: Вимпел К 0,5 л/т + Оракул насіння, 1,0 л/т + Оракул молібден, 0,5 л/т + обробка посівів у фазу 2 - 3 справжніх листки: Вимпел, 0,5 л/га + обробка посівів у фазу початку бутонізації: Вимпел, 0,5 л/га + Оракул бор, 1,0 л/га + Оракул сірка, 2,0 л/га + Оракул цинк, 1,0 л/га.

У середньому за роки досліджень маса 1000 насінин коливалася від 124,0 г до 152,7 г залежно від досліджуваних чинників. Покращення мінерального живлення забезпечувало зростання маси 1000 насінин, порівняно до контролю, на 1,9-4,0 г або 1,5-2,8 \% - за внесення $\mathrm{N}_{32} \mathrm{P}_{32} \mathrm{~K}_{32}$ та 4,3-8,6 г або 3,5-6,0 \%- за внесення $\mathrm{N}_{48} \mathrm{P}_{48} \mathrm{~K}_{48}$. Досліджувані способи допосівної обробки насіння та позакореневого підживлення посівів сої забезпечили зростання маси 1000 насінин на варіантах без основного мінерального живлення на 1,7-20,1 г або $1,4-16,2 \%$, за внесення $\mathrm{N}_{32} \mathrm{P}_{32} \mathrm{~K}_{32}-$ на 4,6-22,2 г або 3,6-17,6 \%, за внесення $\mathrm{N}_{48} \mathrm{P}_{48} \mathrm{~K}_{48}-$ на 6,1-24,4 г або 4,7-19,0\%.

Відомо, що оптимальне значення індексу урожаю, який розраховується за формулою Дональда як відношення маси насіння до загальної маси врожаю (вегетативна маса + репродуктивна маса) становить у середньому 0,50 ум. од., змінюючись у діапазоні від 0,35 ум. од. до 0,65 ум. од. За нашими підрахунками індекс урожаю змінювався від 0,46 ум. од. до 0,53 ум. од. Найнижчим він був на варіанті без удобрення та позакореневого підживлення, найвищим - на варіанті комплексної допосівної обробки насіння та обробки посівів у фази 2-3 листків і бутонізації за рівня мінерального живлення $\mathrm{N}_{48} \mathrm{P}_{48} \mathrm{~K}_{48}$.

Встановлено, що індекс урожаю змінювався за рівнями мінерального живлення: від $0,46-0,50$ ум. од. та $0,46-0,51$ ум. од. - на контролі без добрив та за внесення $\mathrm{N}_{32} \mathrm{P}_{32} \mathrm{~K}_{32}$, до $0,47-0,53$ ум. од. - за внесення $\mathrm{N}_{48} \mathrm{P}_{48} \mathrm{~K}_{48}$. За досліджуваними способами допосівної обробки насіння та позакореневого підживлення індекс урожаю зростав від $0,47-0,49$ ум. од. - за умови проведення лише допосівної обробки насіння до $0,50-0,53$ ум. од. - за комбінованої обробки посівів, тоді як на контролі цей показник становив $0,46-0,47$ ум. од.

Таким чином, узагальнюючи вищевикладене, можна підсумувати, що найбільше зростання показників індивідуальної продуктивності в середньому за три роки досліджень: кількості бобиків - на 26 шт., 
насінин у бобику - на 0,2 шт., маси 1000 насінин - на 30,2 г або 22,7 \% відмічено на варіанті, де передбачалась обробка насіння: Вимпел К 0,5 л/т + Оракул насіння, 1,0 л/т + Оракул молібден, 0,5 л/т + обробка посівів у фазу 2-3 справжніх листки: Вимпел, 0,5 л/га + обробка посівів у фазу початку бутонізації: Вимпел, 0,5 л/га + Оракул бор, 1,0 л/га + Оракул сірка, 2,0 л/га + Оракул цинк, 1,0 л/га за рівня мінерального живлення $\mathrm{N}_{48} \mathrm{P}_{48} \mathrm{~K}_{48}$.

\section{Література:}

1. Гадзовський Г. Л., Новицька Н. В., Мартинов О. М. Фотосинтетична діяльність посівів сої на дерново-підзолистих грунтах Західного Полісся. Рослинництво та грунтознавство. 2020. Том 11. № 1. C. 5-12. http://dx.doi.org/10.31548/agr2020.01.005

2. Каленська С. М., Новицька Н. В. Ефективність нанопрепаратів у технології вирощування сої. Рослинництво та трунтознавство. 2020. Том 11 № 3. С. 7-21. DOI: http://dx.doi.org/10.31548/agr2020.03.007

3. Лихочвор В. В., Щербачук В. М., Панасюк Р. М., Панасюк О. В. Вплив удобрення на формування фотосинтетичної та зернової продуктивності сої в умовах Західного Лісостепу. Передгірне та гірське землеробство і тваринництво. 2016. Вип. 60. С. 88-95.

4. Шевчук В. В., Ходаніцька О. О., Ткачук О. О., Шевчук О. А., Поливаний С. В. Продуктивність сої культурної за використання препаратів ріст регулюючого типу. The scientific heritage. 2021. № 61. С. 6-10.

5. Шепілова Т. П. Вплив регуляторів росту на продуктивність сої в умовах Північного Степу України. ВІСНИК Полтавської державної аграрної академії. 2019. № 3. С. 80-84.

6. Zabarna T. A. The formation of soybean phitocenosis and seeds guality depending on the intensification factors. Сільське господарство та лісівниитво. 2020. № 19. С. 98-109. DOI: 10.37128/2707-5826-2020-4-9. 